\title{
Determinants of Commercial Bank Growth
}

\author{
With Special Reference To Large Banks in the \\ Eighth Federal Reserve District
}

\author{
by SUSAN SCHMIDT BIES
}

\begin{abstract}
The strength of the local economy and prevailing legal restrictions have an important influence on the growth of commercial banks. This article relates these factors to the growth of the largest commercial banks in the Eighth Federal Reserve District.
\end{abstract}

\begin{abstract}
C OMMERCIAL banks are an important factor in the economic development of an area. They are a major supplier of credit and the only source of demand deposit services which help facilitate business transactions. In recent years, commercial banks have introduced activities greatly diversified from their traditional loan and deposit services, including trust departments, travel agencies, insurance agencies, intemational banking services, credit card services, payroll accounting, and data processing. While banks of all sizes provide credit to individuals and smaller businesses, only large banks have sufficient capital to meet the credit demands of large corporations and operate at a scale where more specialized banking services can be provided efficiently.
\end{abstract}

In order to reduce the risk of their loan portfolio, banks diversify their loans with respect to borrower, purpose, and size of loan. Small banks, with their proportionately small loan and investment portfolio, thus limit their extensions of credit to relatively smaller and less specialized types of loans. The size of a loan a bank can make is further constrained by legal restrictions requiring a loan to any one customer to be less than a given percentage of the bank's capital, usually about 15 percent. Thus, customers requiring large amounts of credit generally utilize large banks.

The more populated an area, the greater the demands for more specialized ancillary banking services. Smaller banks compete efficiently in supplying basic banking services, but their limited scale of operations does not provide a sufficient return for them to employ the skilled personnel to introduce more special- ized loan services, trust services, payroll accounting, and foreign banking services. Larger banks can efficiently provide these services, however, and thereby facilitate business activity.

This article analyzes the growth of the largest commercial banks in the Eighth Federal Reserve District over the past six years. Basic economic and legal factors determining the scale of bank operations are discussed first. The performance of large district banks is then examined to determine the impact of these factors on their growth.

\section{Determinants of Bank Size and Growth}

The scale of operations of a bank is determined in part by its resource supply and the demand for its services and in part by legal restrictions. The main financial resources of an individual bank are derived from deposits, and deposits of the entire banking system are limited by bank reserves. Banks facing a rising local demand for loans try to attract savings from outside the region, adding to their deposits and increasing the supply of loanable funds. These additional loans, in tum, help to generate further economic growth in the area.

Bank size is also affected by state and Federal bank structure laws and restrictions on bank operations. Laws which restrict bank operations to one location, interest rates paid on deposits, or rates charged for loans limit the ability of banks to compete for deposits and supply customer demands for banking services. These restrictions may place banks in one location at a competitive disadvantage with banks in other areas 
and with other financial institutions. They may also tend to reduce the efficiency of banks in acquiring and investing resources.

\section{Dontends for bank Serwices}

Both the financial cost and the time involved in travel to a bank to transact business serve to effeetively limit the geographic area over which customers shop for bank services. Since travel costs are not dependent upon the size of a deposit or loan, as the size of the transaction rises the per dollar travel cost of the service decreases. The geographic market of the customer is thus enlarged as the size of his transaction grows. Surveys indicate that convenience to home or place of work is one of the prime factors influencing the choice of a bank for households and small firms. ${ }^{1}$ Thus, bank offices located in rapidly growing industrial and residential areas usually experience greater expansion than offices located in stable or declining areas.

While local economic factors are of prime impor tance to smaller banks, large banks are less influenced by conditions in their immediate area. Since legal restrictions and efforts to diversify the risk of loan portfolios limit the size of loans, the customers to whom small banks lend are those who use neighborhood banks. In contrast, large banks extend many loans to large corporations in distant locations who use the services of banks located in a wide geographic area. Thus, large banks may have customers throughout the nation and even in foreign countries, so that their growth is only partially determined by the strength of the local economy. With greater access to resources, such banks can realize advantages of large scale operation and provide more efficient financial service to local firms, thereby encouraging additional local employment and income.

Since large commercial banks strpply the financial demands of customers in regional, national, and international money markets, conditions in these markets have a greater relative effect on large banks than

ISee George Kaufmen, Business Firms and Hotuseholds View Commeriol Banks, and Customers View Bank Markets and Services; A Survey of Elkhart, Indiana, Federal Reserve Bank of Chicago (1967). Theodore $G$. Flechsig, Banking Market Structure and Performance in Metropolitan Areas, Board of Govemors of the Federal Reserve Sxstem (1965), fonnd 90 percent of business loans in amounts of less than $\$ 100,000$ were from banks within the metropolitan area where the frm was located. Clifton B. Luttrell and William E. Pettigrew, "Banking Markets for Business Fims in the St. Lowis Area", this Review (September 1966), pp. 9-12, surveyed business loans and formd that 77 percent of loans to firms with net worth less than $\$ 750,000$ were made to firms located within 15 miles of the bank, while only 48 percent of loans to larger corpontions were made within this distance. they do on small banks which do not service these markets. An example of this is the differing growth rates of time deposits at large and small banks during the 1969-1970 economic contraction. For all U.S. banks, negotiable certificates of deposit (CDs) over $\$ 100,000$ grew at an annual rate of 13.1 percent from January 1966 to December 1969, above the 11.6 percent growth of smaller time deposits. Large corporations, which hold CDs primarily at major commercial banks, withdrew many of these funds when narket interest rates began to exceed Regulation $Q$ ceilings in late 1968. Between December 1968 and February 1970 , large negotiable CDs fell at a 48 percent annual rate, while smaller time deposits continued to grow, but at a very slow one percent rate. This sharp contraction of large $C D$ s was a major factor contributing to the 12.8 percent rate of decline of time deposits at all large U.S. banks in this period." Time deposits at smaller banks continued to increase, but by a smaller rate of expansion of 5.6 percent.

From February 1970 to June 1971 all types of time deposits again began to rise at faster rates, and both large and small commercial banks in the nation experienced more rapid growth. Households increased their savings to near record levels as small time deposits rose at a rate of 17.1 percent, and large CDs more than recovered from their previous decline, increasing at the exceptionally high rate of 101 percent. The ability of large banks to again attract their more traditional source of funds was partially due to the elmination of a ceiling rate on short-term CDs in June 1970 and the decline in other short-term interest rates.

\section{Lromonos of Scale}

Efficiencies induced by bank growth depend upon the initial size of the bank since economies of scale vary over the range of possible sizes of bank opera tions. ${ }^{3}$ Increased scale of operation causes the greatest reduction in marginal costs in the range of production where economies of scale are the greatest. Avail-

2Data for large U.S. commercial banks include all weekly reporting banks.

See Frederick W. Bell and Neil B, Murphy, Costs in Commercial Banking, Research Report No. 41 Federal Reserve Bank of Boston (1968); George I. Benston "Economies of Scale and Marginal Costs in Banking Operations," The National Banking Reviet (June 1965), pp. 507-49; Lyle $\mathrm{E}$. Gramley, A Study of Scale Economies in Banking, Federal Reserve Bank of Kansas City (1962); Stuart I. Creenbaum, "A Study of Bank Costs," The National Banking Reviete (Iune 1967), pp. 415 -34.

${ }_{4}^{4}$ Economies of scale accur when total costs per unit of goods or services produced fall as the size of the firm, measured 
able evidence indicates these larger cost reductions occur as banks grow to $\$ 10$ million in assets. In the intermediate size range ( $\$ 10$ to $\$ 200$ million total assets), modest economies of scale are still evident, thereby encouraging banks to grow further to reduce unit costs and provide lower priced services to customers. Only for the largest banks (over $\$ 200$ million in assets) is there considerable disagreement over the extent of economies of scale. The existence of such a large size range, $\$ 10-200$ million in assets, where the rate of decline of marginal costs is relatively small permits both large and small banks to compete in the same market.

\section{Legu Comanthes}

Although intended to protect the public, state and Federal regulation of bank entry and interest rates may prevent banks from realizing minimum operating costs per unit of output. The problen of measuring the efficiency of banking is a difficult one. But the wide variations from one community to another in rates paid on deposits, rates charged on loans, and prices of other bank services point to the possibility of inefficiencies in our banking system. Whether or not these constraints are the cause of such inefficiencies, measures of bank performance under different laws and regulations offer clues to improved operation of our banking system.

Bank eniry. Entry into banking is restricted by state and Federal regulatory agencies, who frequently deny applications to establish a new bank or office. Bank charters are often denied on the basis that existing banks are meeting demands of customers in the area and prospective profits of an additional bank are poor. The review of an application to establish a new bank or branch office may take regulatory agencies a year. Thus, after a decision is made to organize a new bank, a long period of time may elapse before it is established. Until new banks open and increase competition in the market arca, the existing banks continue to receive the benefits of a market with restricted entry.

Regulated entry also tends to protect inefficient banks, thereby increasing the costs of bank services to the community. In an industry where new firms may be established freely, new entrants increase the pressure on existing firms to operate at maximum efficiency. Those who cannot operate profitably are forced

by output, is increased, Marginal cost is the additional cost incurred for producing an addikional unit of output. out of the market. The restricted entry into banking, however, diminishes this impetus to efficiency.

Interest rate restrictions. Federal and state interest rate ceilings on deposits and usury laws also tend to reduce financial services provided by commercial banks and misallocate funds anong possible uses. Federal interest rate restrictions, which are uniform across the nation, hinder the ability of banks to obtain deposits when customers can receive higher returns from their money elsewhere. Those large commercial and industrial firms able to obtain funds in central capital markets are benefited, while consumers, real estate purchasers, and small businesses which rely on local financial institutions are at a great disadvantage.

State usury laws impinge primarily on small, high risk borrowers. The dollar size of a loan has only a small effect on handling and processing costs. To cover this relatively constant cost, the interest rate on a small loan may be higher than on a large loan of equal risk. In addition, usury laws do not permit adjustments to higher rates to offset greater risks; therefore, as interest rates rise, risky and smaller loans are usually tumed down first. Thus as market interest rates rise above usury rates, individuals and smaller business firms are often unable to obtain funds.

The growth potential of banks is also ctiminished in states where interest rate limitations are more restrictive than those which prevail in other states. When a state's interest ceilings on deposits and loans are below levels in adjacent states, its banks may have difficulty competing with banks in neighboring states which do not face such strict regulation.

Bank structure. The structure of commercial banking in the United States is primarily a result of both state and Federal legislation. Each state determines whether branch bamks and bank holding companies will be permitted to operate. Federal legislation limits the acquisition of banks by holding companies in the absence of state restrictions and the type of activities in which nonbank subsidiaries of bank holding companies can engage. Approval of mergers and new branches is made by several agencies, depending upon whether the banks involved have a state or national charter and whether they are members of the Federal Reserve System and the Federal Deposit Insurance Corporation. Where a Federal agency has supervisory functions, state bank structure laws must still be followed.

\footnotetext{
"See Clifton B. Lattrell, "Interest Rate Controls - Perspective. Purpose and Problens," this Review (September 1968 ) pp. 6-14, and Charlotte E. Ruebling, "The Administration of Fegulation Q," this Revew (February 1970), pp. $29-40$.
} 
Each state has jurisdiction over whether banks can establish additional offices, whether these offices can offer complete banking services or only perform limited functions, and the geographic area in which these offices can be located. Fifteen states prohibit the establishment of any full-service branches, but most of these states do allow the operation of at least one limited service facility. Sixteen states permit branches within the county or counties contiguous to where the home office is located, although some do not allow branches in cities where the home office of another bank is located. Only nineteen states permit statewide branching. ${ }^{6}$ Federal law permits a holding company to acquire banks in states where not explicitly prohibited by state law if other activities of the holding company are permissible and additional competitive restraints are met as determined by law and the decisions of the Federal Reserve Board.

Evidence as to which banking structure provides better performance is not conclusive. One problem is the lack of clearly defined measures of efficiency. Possible criteria could include prices of services, quality of service, number of offices per capita or per square mile to indicate convenience, and the range of services provided.

Prices of bank services do not show any marked difference with respect to bank structure. This is in part due to the large degree of nonprice competition in banking, especially in functions where other financial institutions do not compete with banks, such as checking accounts. The strong reliance on nonprice competition results in part from Federal and state restrictions on interest rates. The differing competitive positions and regulations applying to nonbank financial institutions also affect prices and quality of bank services, thereby influencing measures of bank performance even under the same bank structure laws.

Measures of convenience and cost also lead to inconclusive results concerning optimm bank structure. More bank offices per capita are in operation in metropolitan areas where branch banking prevails. ${ }^{8}$ In

"See "Recent Changes in the Structure of Commercial Banking," Federal Resterve Bulletin (March 1970), pp. 195-210, for description of state banking laws.

TSee Franklin R, Edwards, "Concentration in Banking and its Elfect on Business Loan Rates," The Review of Economics and Statistics (August 1964), pp, 294-300; Paul M. Horvitz and Bernard Shull, "The Impact of Branch Banking on Baxk

Performance," The National Banking Review (December

1964), pp. 143-88; Irving Schweiger and John S. MoGee,

"Chicago Banking," The Joumal of Business (July 1961) pp. $203-366$

sHorvitz and Shull, "Branch Banking." rural areas, however, the evidence is not so clear. Towns of less than 5,000 population have an average of one bank office under all types of banking systems, with towns in unit banking states having an almost negligible advantage. In branching states, cities with 5,000 to 25,000 population have more bank offices than similar size cities in unit banking states and the margin of difference increases with town size. For a state as a whole, statewide branch systems provide more bank offices per capita than unit or limited branch systenss. Population per bank office averages 6,029 in unit banking states, $5,569 \mathrm{in}$ limited branching states, and 4,908 in statewide branching states. ${ }^{9}$

Branch banks, except for the largest size groups, tend to have slightly higher costs than unit banks of the same size."10 However, cost measures of banks do not reflect the costs paid by the customer in travel to a bank. To the extent that some banking structure systems operate fewer offices than others, thereby making them less convenient to customers, the additional time and travel costs of the customer should be considered in any comparative cost analysis.

The rapid expansion of multiple and one-bank holding companies in recent years is evidence that competition and new bank technology may be exerting increasing pressure on banks to extend their geographic market and scate of operations. Smaller banks which cannot afford to independently operate the new computer systems to increase efficiency in clearing checks and processing loan and deposit accounts are increasingly calling on larger banks to perform these operations. In some cases, small banks have affiliated with holding companies to more efficiently obtain these services. Through a holding company, banks are also able to operate in a wider geographic market and realize decreased total advertising costs. The number of multiple bank holding companies in the United States has increased from 47 in 1956 to 111 at the end of 1970, and these companies are most prevalent in unit and limited branching states.

The growth of one-bank holding companies in the last ten years prompted the passage of amendments to the Bank Holding Company Act in December 1970. These amendments brought an estimated 1,200 onebank holding companies under regulation by the Federal Reserve Board for the first time. Many banks

\footnotetext{
"Branches in operation on December 31, 1970, Federal Rem serve Bulletin (April 1971), p. A95, and population data from U.S. Department of Commerce, Burean of the Census, "1970 Census of Population - Final Population Counts."

10See Benston, "Economies of Scale," and Greenbaum, "Bank Costs."
} 


\begin{tabular}{|c|c|c|}
\hline \multirow[b]{2}{*}{ Ronk } & RGEST COMMERCIAL BANKS IN THE & EEIGHTH \\
\hline & Bank & $\begin{array}{l}\text { Total Assets } \\
\text { June } 9971 \text { thousands }\end{array}$ \\
\hline 1 & $\begin{array}{l}\text { Mercomile Trusl Company National Assoelation } \\
\text { St louls Missoun }\end{array}$ & $\$ 1,326,983$ \\
\hline 2 & $\begin{array}{l}\text { Firs Netional Bant nstsous } \\
\text { St Louts, Missourt }\end{array}$ & $1,031,403$ \\
\hline 3 & The Fist National Bort of Menphis & 937,700 \\
\hline 4 & Union Blanfers Nationol Bank of Memphis & 869,940 \\
\hline 5 & $\begin{array}{l}\text { Citizens flodelly bonk \& Trust Conpony } \\
\text { Lousville, Kentudky }\end{array}$ & 667,321 \\
\hline 6 & 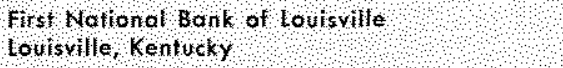 & 568,322 \\
\hline 7 & She Boolmen's Wetional Bonk of st louts & 357094 \\
\hline 8 & Liberty Notional bonk ond $1+4 s \mathrm{Company}$ & 343,793 \\
\hline 9 & Notional Bonk of Commere & 207,845 \\
\hline 10 & $\begin{array}{l}\text { Bonk of loulswile Royol Bonk and } \\
\text { Trusilleompony }\end{array}$ & 264698 \\
\hline 11 & $\begin{array}{l}\text { Worthen Bank ond Tust company } \\
\text { Uitle Rock, Arkansos }\end{array}$ & 254,877 \\
\hline
\end{tabular}

adopted this form of organization with the expressed purpose of expanding the scope of both their financial and nonfinancial activities and to obtain efficiencies in the performance of traditional banking functions. ${ }^{11}$

\section{Growth of Large Eighth District Banks}

The factors discussed above have had an important effect on the growth of large commercial banks in the Eighth Federal Reserve District. Three of the eleven largest Eighth District banks are located in St. Louis,

11While such inducements to expatad banking organizations exist, proponents of a unit banking system argue that the government should prevent the expansion of banking concentration through branch banking and bank holding comparies. The major arguments against branch banking and bank holding companies include the following:

1) Funds are exported from the local comminity.

2) Malagers are not sympathetic to the demands of local customers.

3) Unnecessary delays arise between the time the application is made for a loan and its approval by the home office.

4) The local banking market is more likely to be monopolistic.

5) Mismanagenent on a large scale can arise more easily than in an independent unit bank.

6) Multiple office banking tends toward monopolistic control of the nation's banking resources.

For a further discussion of these points see W. Ralph Lamb, Group Banking (New Brunswick, N.I.: Rutgers University Press, 1961).

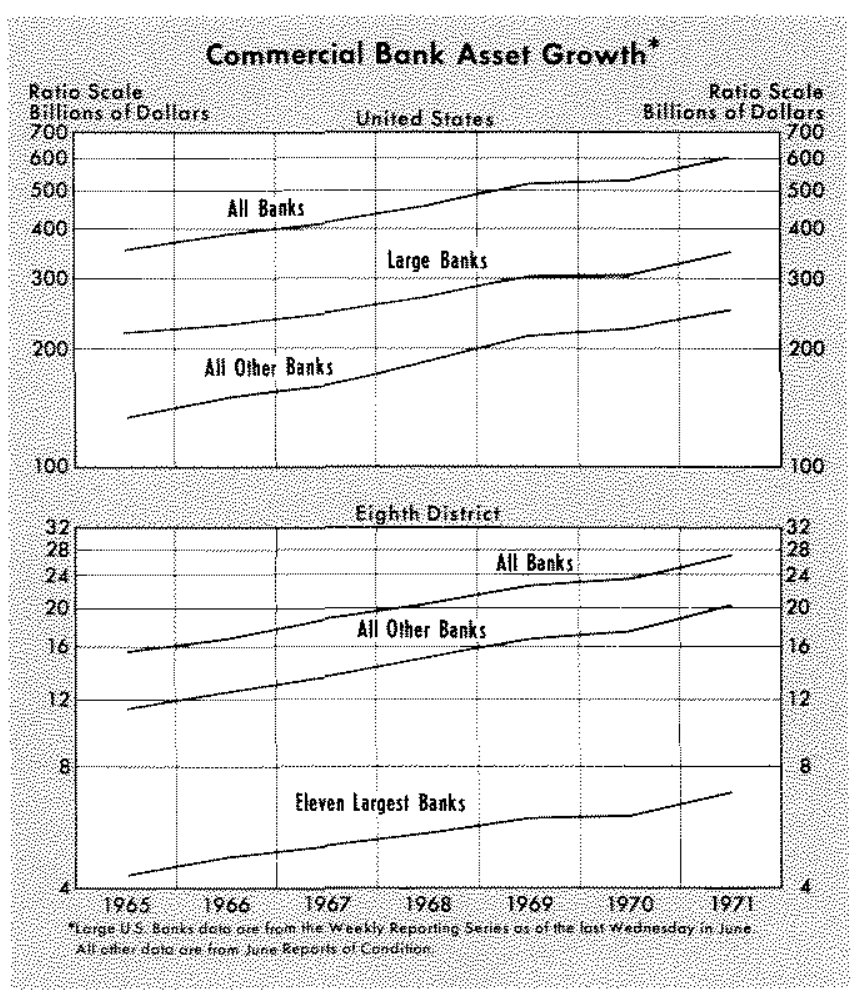

three in Memphis, four in Louisville, and one in Little Rock (see Table I). ${ }^{12}$ Deposits, loans, and assets of these banks increased at rates comparable to those of large banks elsewhere in the country during the period from June 1965 to June 1971 (see Table II and accompanying chart). Total assets of the eleven banks combined increased at an average annual rate of 8.2 percent between June 1965 and June 1971, slightly above the 8.1 percent rise of all large commercial banks in the United States, yet significantly below the 9.9 percent increase in assets of other Eighth District banks. Thus, the share of district deposits held by the eleven large banks declined over the six year period.

On an individual basis, seven of the eleven banks maintained growth rates exceeding the combined growth for all large U.S. banks, one had a growth rate about equal to that of large U.S. banks, while the three St. Louis banks experienced significantly slower rates of growth. Annual growth of total assets of the three St. Louis banks averaged 5.6 percent between June 1965 and June 1971, about half the average rate of increase of large banks in each of the other three district cities. The rates of growth for the large banks in Memphis, Louisville, and Little Rock averaged 9.3, 11.1 , and 11.9 percent, respectively. These varying

1.2The large banks described in this article are the eleven Eighth District banks reporting total deposits exceeding $\$ 200$ million on June 30,1971 . 


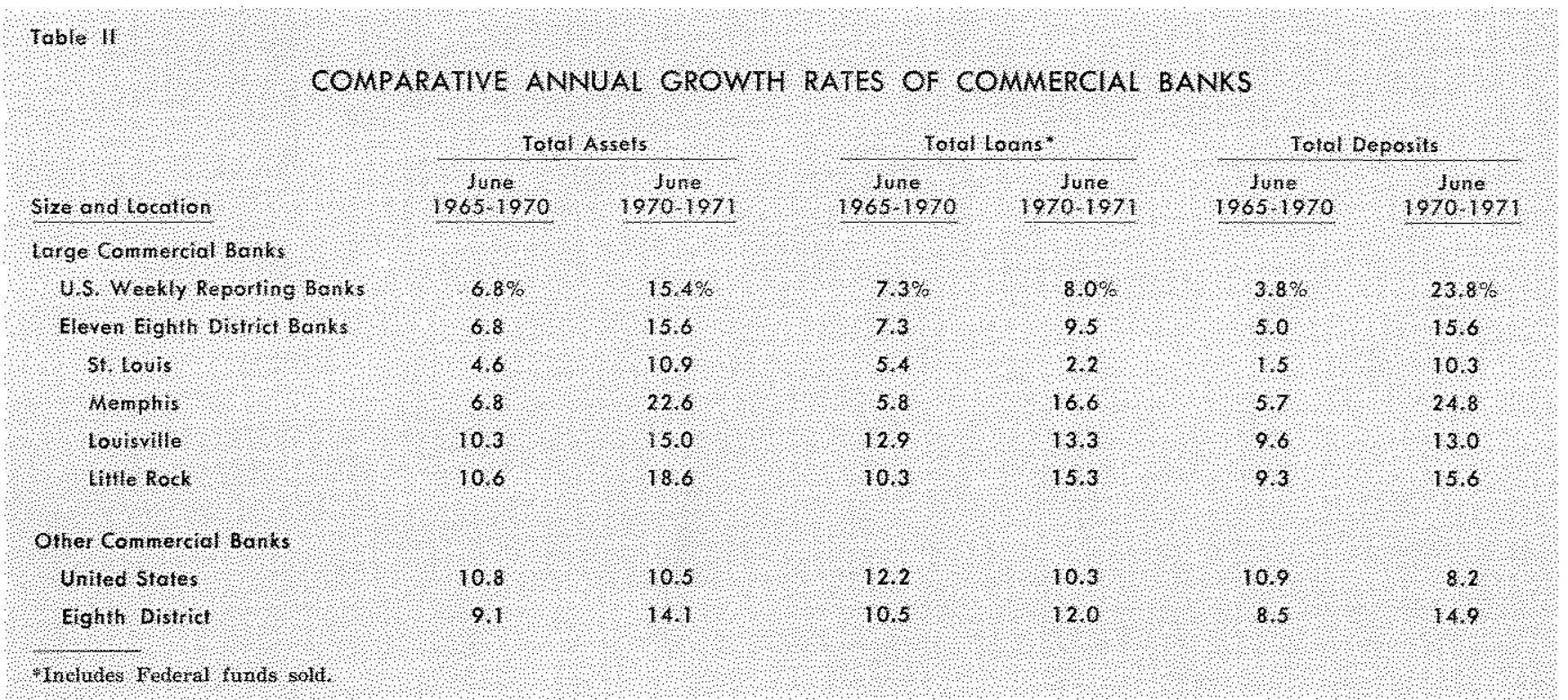

rates of growth of the large district banks rellect the diverse economic conditions and legal restrictions prevailing among these metropolitan areas.

The rate of growth of the largest district banks fell during the general economic slowdown in 1969 and 1970. Between June 1970 and June 1971, however, the eleven banks resumed a more rapid growth rate. In the later period, assets rose at an average annual rate of 15.6 percent, close to the 15.4 percent increase of large U.S. commercial banks, above the 14.1 percent rise for all other district banks, and twice the average 6.8 percent rate of growth of these eleven banks from June 1965 to June 1970.

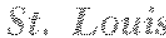

The growth rate of large St. Louis banks has been well below that of other large district banks in the last six years. Mercantile Trust Company National Association, First National Bank in St. Lous, and The Boatmen's National Bank of St. Louis rank first, second and seventh largest in the district, respectively, on the basis of total assets (see Table I). Their slower growth relative to other banks in the district and elsewhere in the country reflects several factors, among which are the comparatively slower growth of the St. Louis Standard Metropolitan Statistical Area (SMSA) and the unit banking structure of Missouri.

Between 1965 and 1970, payroll employment in the St. Louis SMSA increased at an annual rate of 2 percent, below the rates for the United States and the Little Rock SMSA, and only half that of the Louisville: and Memplis SMSAs (see Table III). Population of the St. Louis SMSA grew at a 1.2 percent annual rate from 1960 to 1970 , somewhat slower than the nation and the Memphis and Louisville SMSAs, and well below the 1.7 percent annual growth of the Little Rock SMSA.

The large St. Louis banks are in the downtown area and, like other central cities in which large district banks are located, St. Louis has not kept pace with the rapid growth of its suburban areas. St. Louis had a net loss of manufacturing firms and retail stores and only a 2.4 percent increase of service establishments between 1963 and 1967, while in the portions of the St. Louis SMSA outside the city, manufacturing, retail, and service establishments increased by 7.9 , 7.5 , and 28.8 percent, respectively. ${ }^{13}$

Unlike banks in Memphis and Loulswille, the unit banking restrictions in Missouri have prevented the large St. Louis banks from establishing branches in these expanding suburban areas. ${ }^{1+}$ In an effort to serve customers in the more rapidly growing areas of the state, most large Missouri banks have recently fomed multiple bank holding companies. Since September 1970 , the three St. Louis banks have each formed such a holding company. In addition to their lead banks, these holding companies have received Federal Reserve Board approval to acquire a total of fouteen banks in suburban St. Louis and outlying areas of the state.

13 U.S. Department of Commerce, Bureau of the Census, Census of Manufacturers and Census of Business, 1963 and 1967.

ftrhe state constitution prevents Missouri banks from operating branches. They may, however, operate one limited service facility within 4,000 yards of the head office. 


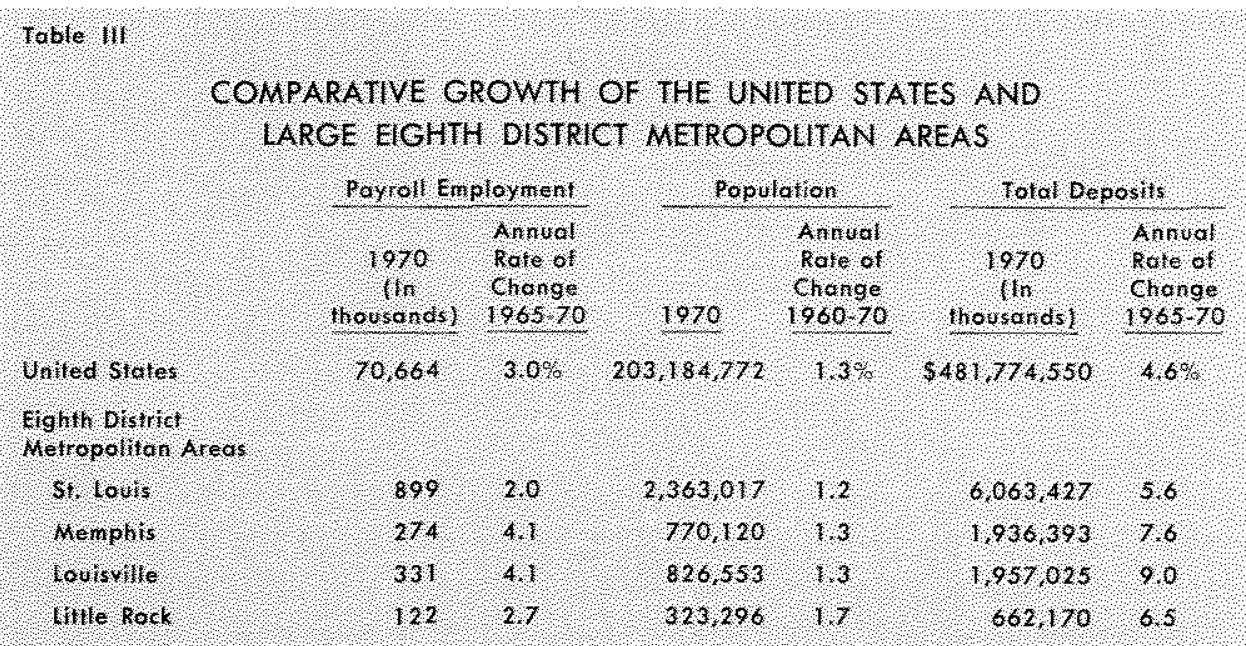

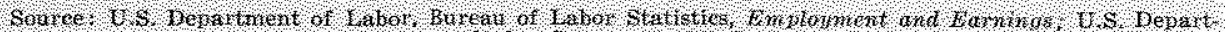

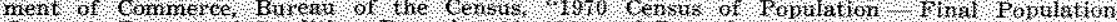

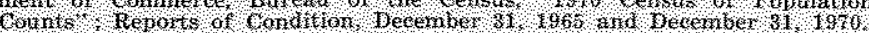

nerships, and corporations (IPC) at these banks fell at a 3.6 percent annual rate. From the time the state ceiling was removed in mid-1969 to December 1969, these deposits rose again to December 1968 levels. The ability to again compete for traditional sources of deposit funds enabled these banks to expand while total IPC time and savings deposits at all large commercial banks in the United States were falling.

Temnessee law permits the establishment of branches throughout the county where the home office is

\section{Memphis:}

The three largest Memphis banks are: The First National Bank of Memphis, the third largest bank in the district; Union Planters National Bank of Memphis, the fourtl largest; and National Bank of Commerce, the ninth largest. Between June 1965 and June 1971, their combined assets increased at an annual rate of 9.3 percent, above the combined growth rate of all district banks and that of all large U.S. banks. The slower growth of these Memphis banks relative to some other large district banks from 1965 to 1970 can be largely attributed to excessive state restrictions on interest rates which prevailed during most of the period. Until mid-1969, interest mtes paid savers were limited to 4 percent, and rates charged on loans were generally limited to 6 percent. From June 1965 to June 1970 combined assets of these Memphis banks increased at a rake of only 6.8 percent. In the year ending in June 1971, however, these banks increased their combined assets by 22.6 percent, far above the average rates of growth of large distuict banks in other cities. This exceptionally high rate of growth reflects both the strong economic position of the area and the relaxation of state interest rate ceilings which permitted the banks to compete more effectively for loans and deposits.

In late 1967, when money market rates began to rise substantially above the interest rate ceilings set for Tennessee banks, the Memphis banks could not compete effectively for deposits with other financial institutions and banks located in adjacent Mississippi and Arkansas. Between December 1968 and Jume 1969, time and savings deposits of individuals, part. located. Because of the faster growth of employment and population in the Memplis suburban areas, deposits at branch offices in these areas of Shelby Comnty have expanded much more rapidly than at offices within the City of Memphis. Between June 1968 and June 1970, total deposits at Memphis offices of the three largest Memphis banks increased at a 3.1 percent annual rate, while deposits at their suburban branches increased at a rate of 17.1 percent. In June 1971. the number of branches and drive-in facilities of these banks totaled 81 , an increase of 22 offices since 1965.

In addition to their ability to reach new customers through branches, two of the three Memphis banks are lead subsidiaries of bank holding companies. First Tennessee National Corporation, a one-bank holding company owning First National Bank of Memphis, has received Federal Reserve Board approval to acquire one bank in eastern and one bank in central Tennessee and has announced agreements to acquire three additional banks. In December 1970, National Bank of Commerce was approved as a subsidiary of United Tennessee Bancshares Corporation, which has thee other bank subsidiaries and has announced plans to acquire one additional bank.

\section{Ionsing}

The 11.1 percent average annual growth of assets of the four large Louisville banks from June 1965 to June 1971 exceeds that of the total of large U.S. com mercial banks and the average growth of other district bakks. Citizens Fidelity Bank and Trust Company, First National Bank of Louisville, and Liberty 
National Bank and Trust Company are the fifth, sixth, and eighth largest banks, respectively, in the district. Bank of Louisville-Royal Bank and Trust Company, the tenth largest bank, had the highest rate of increase of assets of all large district banks during the last six years. Its 15.8 percent annual rate of increase in assets is almost twice the growth rate of large U.S. commercial banks.

The strong growth of the major Louisville banks reflects the absence of overly restrictive state interest rate ceilings, the ability of these banks to establish branches in the growing suburban areas, and the continued economic expansion of the Louisville metropolitan area. The unemployment rate in the Louisville SMSA was one percentage point below the national level until the spring of this year.

Like Temessee, Kentucky law permits banks to establish branches within the county where the head office is located. The large Louisville banks have branched extensively throughout Jefferson County where industry and population are growing fastest. Between J me 1968 and June 1970 deposits at suburban branches of these four banks increased at an annual rate of 18 percent, three times the 6 percent deposit growth at their offices in Lousville. As of June 30,1971 , these banks operated a total of 103 branch offices in Jefferson County, 21 of which have opened in the last six years. Kentucky law effectively prevents the operation of multiple bank holding conpanies by limiting the share of a bank's stock that a corporation can own to less than 50 percent.

\section{Lithe Rock}

Total assets of Worthen Bank and Trust Company, Little Rock, the largest bank in Arkansas, increased at an annual rate of 11.9 percent between June 1965 and June 1971. This growth is significantly greater than that of all large U.S. banks, and in contrast to most large district banks, Worthen Bank and Trust Company has maintained its share of total state deposits during this period. The ability of Worthen Bank and Trust Company to maintain a high rate of growth, while the large unit banks in St. Louis did not, results in part from the ability of Arkansas banks to establish limited service offices within the county of the head office and from the faster growth of the City of Little Rock.

The Little Rock SMSA has been attracting new business firms at a rate greatly exceeding that of other large district SMSAs and thereby kept its unemployment rate below four percent throughout the business contraction of 1969-1970. The number of manufacturing, retail, and service firms in the Little Rock SMSA increased by 31.5 percent between 1963 and 1967, five times the average 6.4 percent increase of the three other large district SMSAs and the 5.9 percent rise for the United States.

In June 1971, Worthen Bank and Trust Company operated nine limited service "teller's window" offices in Little Rock, two of which have been opened since 1965. It has also expanded through the establishment of the only multiple bank holding company in Arkansas, First Arkansas Bancorporation, which has two other subsidiary banks. Within the last year, however, the Arkansas legislature passed a law prohibiting the establishment of additional multiple bank holding companies, thus preventing further expansion of banks through this means.

\section{Conclusion}

In the last six years, the combined resources of the large Eighth District banks increased at rates nearly equal to the average of large commercial banks elsewhere in the nation. On an individual basis, the large district banks experienced markedly different annual rates of growth, ranging from 4.6 to 15.8 percent. As a group, they did not grow as rapidly as smaller district banks even though they were probably able to realize greater cost economies. This slower growth probably reflects the fact that the larger banks were more affected by the restrictive national monetary policy which prevailed over part of this period.

The basis of the growth of large commercial banks is the economic strength of the geographic market area in which they operate. Those located in faster growing metropolitan areas experienced faster rates of growth. Growth was also higher for those banks that were able to open offices in the more rapidly growing suburban areas. Bank growth was hampered in states where interest rate ceilings on deposits and loans were below rates prevailing in adjoining states.

As in any industry, commercial banks operate best in a competitive market relatively free of regulatory constraints. The judgements which must be made by regulatory authorities to establish usury and deposit interest rate ceilings, and to determine the profitability of new banks, new bank offices, and the effect of mergers and holding company acquisitions are very difficult. These decisions are justified on the basis that they are in the "public interest." It is not altogether clear, however, that they are conducive to maximum competition and minimum cost of bank services to the public. 